\title{
Hubungan Dukungan Teman Sebaya Dengan Kecemasan Remaja Putri Dalam Menghadapi Perubahan Fisik Pada Masa Pubertas Kelas VIII Di SLTPN 31 Semarang
}

\author{
Priharyanti Wulandari ${ }^{1}$, Menik Kustriyani ${ }^{2}$, Ari Fiyanti ${ }^{3}$ \\ 1,2,3 STIKES Widya Husada Semarang \\ email : wulancerank@yahoo.co.id
}

\begin{abstract}
Abstrak
Latar Belakang: Masa pubertas adalah masa transisi remaja mengalami perubahan fisik, emosi dan psikis, perkembangan fisik yang begitu menonjol mengakibatkan cemas, Pada masa ini teman sebaya mempunyai arti yang sangat penting. Tujuan penelitian ini untuk mengetahui hubungan antara dukungan teman sebaya dengan kecemasan remaja putri dalam menghadapi perubahan fisik pada masa pubertas kelas VIII di SLTPN 31 Semarang.Metode: Jenis penelitian ini adalah studi korelasi dengan metode pendekatan cross-sectional. Jumlah sample dalam penelitian ini yaitu 85 siswi yang terdiri dari 8 kelas. Teknik pengambilan sampel simple random sampling. Analisa data dengan uji korelasi rank spearman. Hasil: Ada hubungan dukungan teman sebaya dengan kecemasan remaja putri dalam menghadapi perubahan fisik pada masa pubertas di SLTPN 31 Semarang, dinyatakan dengan $\mathrm{p}$ value $0,000<0,05, \mathrm{rho}=0,675$. Ho di tolak dan Ha diterima.

Simpulan: Ada hubungan antara dukungan teman sebaya dengan kecemasan remaja putri dalam menghadapi perubahan fisik pada masa pubertas di SLTPN 31 Semarang.
\end{abstract}

Kata kunci: Dukungan teman, Kecemasan, Masa Pubertas

\section{Pendahuluan}

Masa remaja adalah masa transisi yang ditandai oleh perubahan fisik, emosi dan psikis. Masa remaja yaitu antara usia 10-19 tahun yang merupakan suatu periode masa pematangan organ reproduksi manusia dan sering disebut dengan masa pubertas. Remaja terjadi perubahan organ-organ fisik secara cepat, dan perubahan tersebut tidak seimbang dengan perubahan mental emosional, terjadinya perubahan besar ini umumnya membingungkan remaja yang mengalaminya. (Widyastuti, 2009).

Pubertas merupakan masa peralihan antara masa kanak-kanak ke masa dewasa. Kejadian yang penting dalam pubertas ialah pertumbuhan badan yang cepat, timbulnya ciri-ciri kelamin sekunder, menarche dan perubahan psikis (Widyastuti, 2009).

Remaja yang tidak mempunyai pengetahuan cukup atau informasi yang jelas tentang perubahan fisik yang mereka alami kadang - kadang akan menimbulkan rasa cemas, takut, malu, merasa lain, dan bingung.
Konsekuensi dari perkembangan fisik ini akan lebih kompleks pada remaja putri. Salah satunya perubahan berat dan bentuk tubuh yang terkadang menganggu geraknya bila ingin terlihat menarik di depan lawan jenisnya (Gunarsa, 2006).

Kecemasan merupakan respon individu terhadap suatu keadaan yang tidak menyenangkan dan dialami oleh semua makhluk hidup dalam kehidupan sehari- hari. (Suliswati dkk, 2005).

Remaja memiliki kebutuhan yang kuat untuk disukai dan diterima kawan sebaya atau kelompok. Sebagai akibatnya, mereka akan merasa senang apabila diterima dan sebaliknya akan merasa sangat tertekan dan cemas apabila dikeluarkan dan diremehkan oleh kawan-kawan sebayanya (Santrock, 2007).

Berdasarkan studi pendahuluan pada tanggal 25 Maret 2015 di SLTP 31 Semarang dilakukan dengan metode wawancara pada 10 remaja putri kelas VIII, di dapatkan hasil 10 remaja putri sudah mengalami menarche, 
delapan remaja putri mengatakan takut, cemas dengan perubahan yang terjadi pada diri mereka, mereka khawatir dengan adanya benjolan di dada, tumbuhnya rambut disekitar alat kelamin, munculnya jerawat serta saat mengalami mentruasi di sekolahan, enam dari delapan remaja yang mengalami cemas, mereka sering berdiskusi dengan teman sebayanya tentang perubahan fisik yang terjadi sehingga cemas mereka berkurang dan merasa lebih tenang, mereka mengatakan sering bermain dengan teman sebayanya di rumah maupun di sekolahan, mereka mengatakan tidak canggung dan bisa terbuka ketika berdiskusi tentang perubahan perubahan yang terjadi pada masa pubertas. Enam remaja tersebut memilki dukungan teman sebaya baik. Dua remaja lainnya yang mengalami cemas tidak mendiskusikan tentang kecemasannya saat menghadapi perubahan fisik kepada siapapun kecuali dengan ibunya, mereka malu untuk bercerita dengan teman sebayanya, dua remaja tersebut memiliki dukungan teman sebaya kurang baik. Dua remaja putri lainnya tidak mengalami cemas ketika mengalami perubahan fisik karena mereka selalu mendiskusikan perubahan yang terjadi pada masa pubertas dengan teman sebayanya di rumah maupun sekolah, mereka juga sering berdiskusi dengan orangtuanya, 2 remaja memiliki dukungan teman sebaya sangat baik. Berdasarkan latar belakang di atas maka peneliti tertarik untuk mengadakan penelitian yang berjudul "Hubungan dukungan teman sebaya dengan kecemasan remaja putri dalam menghadapi perubahan fisik pada masa pubertas kelas VIII di SLTPN 31 Semarang.

\section{Metode Penelitian}

Penelitian ini menggunakan jenis penelitian study korelasi. Desain penelitian ini adalah cross sectional study. Pengumpulan data menggunakan kuesioner. Teknik pengambilan sampel menggunakan simple random sampling didapatkan hasil 85 responden yang sudah mengalami menstruasi. Teknik analisa data menggunakan korelasi Rank Spearman.

\section{Hasil Penelitian}

dukungan teman sebaya kelas VIII sebanyak 8 siswi $(9,4 \%)$ memiliki dukungan kurang baik, 64 siswi $(75,3 \%)$ memiliki dukungan baik, 13 siswi $(15,3 \%)$ memiliki dukungan sangat baik.

kecemasan remaja putri dalam menghadapi perubahan fisik pada masa pubertas diatas dapat diketahui bahwa kecemasan dalam menghadapi perubahan fisik pada masa pubertas sejumlah 18 siswi $(21,2 \%)$ mengalami kecemasan ringan, sejumlah 59 siswi mengalami kecemasan sedang $(69,4 \%), 8$ siswi mengalami kecemasan berat $(9,4 \%)$ dan tidak ada siswi yang mengalami panik.

Berdasarkan Analisa Data dengan uji korelasi rank spearman hasil nilai sig $\rho$ value 0,000 dan nilai rho $=0,675$ dengan taraf signifikan $5 \%$ dapat disimpulkan sig. $0,000<0,05$ maka Ho ditolak dan Ha diterima yang menunjukkan ada hubungan yang bermakna antara dukungan teman sebaya dengan kecemasan remaja putri dalam menghadapi perubahan fisik pada masa pubertas kelas VIII di SLTPN 31 Semarang.

\section{Pembahasan}

\section{Dukungan teman sebaya pada masa pubertas}

Dari hasil penelitian yang dilakukan terhadap 85 responden menunjukkan bahwa yang mendapatkan dukungan teman sebaya kurang baik sebanyak 8 responden $(9,4 \%)$, dukungan teman sebaya baik sebanyak 64 responden $(75,3 \%)$ dan dukungan teman sebaya sangat baik sebanyak 13 responden $(15,3 \%)$.

Hasil penelitian ini menunjukkan bahwa mayoritas remaja putri mendapatkan dukungan teman baik sebanyak 64 responden, sebagian besar responden yang mendapat dukungan baik mereka hampir setiap hari bertemu dan bermain dengan teman sebayanya di sekolah maupun dirumah.

Siswi di SLTPN 31 Semarang ini mendapat dukungan penuh dari teman sebaya berupa dukungan informatif yaitu seperti informasi, saran tentang perubahan fisik yang terjadi pada masa pubertas, Dukungan kognitif, Dukungan emosional, dukungan instrumental. Dukungan dari teman sebaya ini 
sangat penting diberikan kepada siswi karena siswi yang tidak memiliki pengetahuan cukup tentang perubahan perubahan yang terjadi pada masa pubertas mereka sering mencemaskan perubahan yang terjadi pada masa pubertas. Apabila mereka sudah dipersiapkan dan mendapatkan informasi tentang perubahan tersebut maka remaja tidak akan mengalami kecemasan dan reaksi negatif lainnya, tetapi bila mereka kurang memperole informasi, maka akan merasakan pengalaman yang negatif.

Hal ini sejalan dengan teori yang diungkapkan Rin Fibriana (2009) bahwa dukungan teman sebaya sebagai informasi yang diberikan kepada individu sehingga individu merasa dicintai, diperhatikan, dihargai, dan dipandang sebagai hubungan dalam komunikasi dan saling bertanggungjawab.

Dari beberapa pengertian diatas dapat disimpulkan bahwa teman sebaya memiliki peranan yang sangat penting dalam menghadapi kecemasan terhadap perubahan perubahan fisik pada masa pubertas.

\section{Kecemasan dalam menghadapi masa pubertas}

Dari hasil penelitian yang dilakukan didapatkan hasil bahwa kecemasan dalam menghadapi perubahan fisik pada masa pubertas sejumlah 18 siswi $(21,2 \%)$ mengalami kecemasan ringan, sejumlah 59 siswi mengalami kecemasan sedang $(69,4 \%)$, 8 siswi mengalami kecemasan berat $(9,4 \%)$ dan tidak ada siswi yang mengalami panik. Hal ini menunjukkan bahwa mayoritas remaja putri mengalami kecemasan sedang yaitu sebanyak 59 siswi $(69,4 \%)$.

Siswi di SLTPN 31 Semarang ini mengalami kecemasan seperti bagian payudara yang mulai tampak membesar, cemas ketika jerawat mulai bermunculan, khawatir dengan tumbuhnya bulu bulu di sekitar alat kelamin, gelisah saat mengalami menstruasi di kelas dan khawatir dengan bentuk tubuh yang berbeda dengan teman teman lainnya.

Hal ini sejalan dengan teori Dewi (2012), mengungkapkan bahwa pada masa pubertas remaja mengalami masa peralihan atau transisi dari masa anak- anak menuju masa dewasa yang berjalan antara umur 12 tahun sampai 21 tahun dan di tandai dengan adanya perubahan aspek fisik, psikis dan psikososial.

Masa remaja merupakan masa yang penuh gejolak, remaja juga merupakan masa peralihan dari masa kanak-kanak menuju masa dewasa, sehingga psikisnya juga dalam tahap perkembangan dan relatif tidak stabil. Sehingga remaja membutuhkan dukungan dari orang lain seperti teman sebaya dalam menghadapi hal-hal baru dalam hidupnya termasuk dalam menghadapi menarche dan masa pubertas (Soetjiningsih, 2007).

\section{Kesimpulan}

Berdasarkan hasil penelitian pada 85 remaja putri di SMPN 31 Semarang kelas VIII didapatkan hasil:

1. Responden yang memiliki dukungan baik yaitu sebanyak 64 siswi $\quad(75,3 \%)$, sebanyak 8 siswi $(9,4 \%)$ memiliki dukungan kurang baik, 13 siswi (15,3\%) memiliki dukungan sangat baik.

2. Responden yang mengalami kecemasan sedang yaitu sebanyak 59 siswi $(69,4 \%)$, 18 siswi $(21,2 \%)$ mengalami kecemasan ringan, 8 siswi mengalami kecemasan berat $(9,4 \%)$.

3. Ada hubungan yang bermakna antara dukungan teman sebaya dengan kecemasan remaja putri dalam menghadapi perubahan fisik pada masa pubertas kelas VIII di SLTPN 31 Semarang. Nilai rho $=0,675$, sig. $\rho$ value $0,000<0,05$ maka Ho ditolak dan $\mathrm{Ha}$ diterima.

\section{Saran}

1. Institusi

Diharapkan pihak sekolah dapat memberi informasi terkait masa pubertas melalui proses belajar mengajar atau diskusi kelompok untuk mengurangi kecemasan.

2. Bagi siswi

Diharapkan siswi menambah informasi tentang kecemasan dalam menghadapi perubahan fisik.

3. Peneliti

Diharapkan peneliti selanjutnya untuk meneliti faktor-faktor lain yang mempengaruhi kecemasan remaja putri 
dalam menghadapi perubahan fisik pada masa pubertas.

\section{Daftar Pustaka}

Alimul, A.2007. Metode Penelitian Kebidanan Tekhnik Analisa Data. Jakarta Salemba Medika

Al-Mighwar. 2006. Psikologi remaja. Bandung. Pustaka setia

Amie Ristianti.2013. Hubungan antara dukungan sosial teman sebaya dengan identitas diri pada remaja di SMA Pusaka 1 Jakarta.Skripsi

Angelina. 2011. Hubungan antara kualitas persahabatan dengan privasi pada remaja akhir. Fakultas Psikologi. Universitas Gunadharma

Arikunto,s. 2007. Manajemen Penelitian.Jakarta : PT Rineka Cipta

BKKBN. 2012. www.bkkbn.go.id

Christina.2013. Peran teman sebaya dengan kecemasan siswi pada masa pubertas dalam menghadapi perubahan fisik di SMP Swasta Betania Medan.Skripsi

Depkes. 2012. Kesehatan remaja problem dan solusinya. Jakarta: Salemba Medika

Desmita. $2005 . \quad$ Psikologi perkembangan.Bandung.Rosda

Dewi, E. H. 2012. Memahami Perkembangan fisik Remaja.Yogyakarta: Gosyen Publishing.

Dimatteo, M. R. (2005). Social support and patient adherence to medical treatment : a meta analysis. Health Psychology Journal.

Elleny. 2007. Dukungan sosial dan harga diri.Skripsi
Fajarina. L.A. 2007. Hubungan antara pengetahuan tentang perubahan fisik pada dengan gambaran diri remaja putri. Skripsi Sarjana Ilmu Keperawatan. UNDIP

Gunarsa,S.D. 2006. Psikologi perkembangan anak dan remaja. Jakarta: PT BPK Gunung mulia.

Hastono, S. P. 2007. Analisa Data Kesehatan. Fakultas Ilmu Kesehatan Masyarakat Universitas Indonesia.

Hawari, D. 2011. Manajemen stres, Cemas, Depresi. Jakarta : Balai penerbit FKUI

Hidayat. 2012. Metodologi Penelitian. Jakarta : Pustaka pelajar

Hurlock, E, B. 2012. Psikologi perkembangan : Suatu pendekatan Sepanjang rentan kehidupan. Edisi Kelima (Alih bahasa : Istiwidiyanti dan Soedjarwo) Jakarta: Erlangga

Ida Nilawati. 2013. Hubungan dukungan sosial remaja dengan kecemasan remaja dalam menghadapi menarche. Skripsi

Intan dan Iwan. 2013. Kesehatan Reproduksi untuk Mahasiswa Kebidanan dan Keperawatan. Jakarta : Salemba

Kusmiran, E. 2013. Kesehatan Reproduksi Remaja Dan Wanita. Jakarta : Salemba Medika

Notoadmodjo. 2010. Metodologi Penelitian Kesehatan. Jakarta : PT Rineka Cipta

Riskesdes. 2013.www. litbang. depkes. go. Id

Riyanto, A. 2013. Statistik Dekskriptif Untuk Kesehatan.Yogyakarta : Nuha Medika 
Santrock, J.W. 2007. Psikologi Pendidikan (edisi kedua). (Penerj. Tri Wibowo B.S). Jakarta Salemba: Medika

Sarwono, J. 2006. Metode Penelitian Kuntitatif \& Kualitatif. Yogyakarta : Graha Ilmu

Saryono, A. S. 2013. Metodologi Penelitian Kebidanan DIII, DIV, S1 Dan S2. Yogyakarta : Nuha Medika

Sastroasmoro. S. dan Ismael, S. 2010. Dasar - dasar Metodologi Penelitian Klinis. Edisi ke-3. Jakarta : Sagung Seto

Sekar.R.A. 2013. Hubungan antara distress dan dukungan sosial dengan proklanitasi akademik pada mahasiswa dalam menyusun skripsi. Skripsi Sarjana Psikologi Universitas Sahid Surakarta

Siregar,S. 2013. Statistik Parametik untuk Penelitian Kuantitatif. Jakarta : PT Bumi Aksara

Siti. M. 2011. Hubungan antara tingkat pengetahuan tentang perubahan fisik pada masa pubertas dengan konsep diri remaja SMP Negeri 6 Yogyakarta. Staf Pengajar Program Study D-III Keperawatan STIKES Kusuma Bangsa Husada Yogyakarta

Stuart.G.W. 2007.Keperawatan jiwa, Edisi kelima,Jakarta

Sugiono. 2007. Statitsik Untuk Penelitian. Bandung : Alfabeta

Survei Demografi dan kesehatan Indonesia, Kesehatan reproduksi Remaja 2012 (KRR SDKI 2012)

Taylor, S. E. 2006. Helath psychology (4th ed). Boston : McGraw Hill.

Widyaastuti,Yani dkk. 2009. Kesehatan Reproduksi.Yogyakarta: fitranaya
Widyanto, F. 2014. Asuhan Keperawatan Keluarga. Jakarta : Pustaka pelajar

Yusnita, V. 2006. "Pengaruh dukungan sosial teman sebaya terhadap perilaku asertif pada remaja awal". Skripsi

Yustiani dan Endah. 2013. "Perbedaan tingkat kecemasan mengalami pubertas dini pada remaja awal ditinjau dari tingkat dukungan sosial”. Fakultas Psikologi. UNAIR 